\title{
Effect of air exposure, handling stress and imidacloprid on the susceptibility of Crassostrea gigas to Ostreid herpesvirus 1 (OsHV-1)
}

\author{
Rebecca Oliver, Marine Fuhrmann, Paul Hick* \\ Sydney School of Veterinary Science, Faculty of Science, The University of Sydney, Camden, \\ New South Wales 2570, Australia
}

\begin{abstract}
The emergence of the microvariant genotype of Ostreid herpesvirus 1 (OsHV-1 $\mu$ Var) has caused mass mortalities of Pacific oysters Crassostrea gigas, resulting in significant economic losses in Europe, New Zealand and Australia. There is variability in the occurrence and severity of disease caused by OsHV-1, with the disease incompletely described by the known complex interactions between host, environment and pathogen. There is a need to evaluate the role of anthropogenic factors on this disease expression due to the number of interactions between humans and oysters. A controlled in vivo laboratory infection model was used to assess changes to the susceptibility of 6 mo old Pacific oysters to OsHV-1 challenge after pre-exposure to combinations of stressors. Pre-exposure of oysters to a concentration of the pesticide imidacloprid consistent with the higher range of environmental contamination in some estuaries had no impact on their survival or OsHV-1 viral load. Oysters pre-exposed to air for $24 \mathrm{~h}$ prior to OsHV-1 challenge by cohabitation were more resilient to infection. Moderate physical handling that simulated onfarm handling did not affect survival. This indicates that farm management practices implemented prior to OsHV-1 exposure might not specifically predispose oysters to more severe disease, and more complex confounding factors need to be considered. It is likely that changes in host physiology during emersion provide the host with increased resilience to disease caused by OsHV-1. Continued investigation of the effect of air exposure in the field will aid in validating the results from this laboratory experiment.
\end{abstract}

KEY WORDS: Bivalve $\cdot$ Pathogen $\cdot$ Pesticide $\cdot$ Farming practice $\cdot$ Risk factor

\section{INTRODUCTION}

In France in 2008, a microvariant genotype of Ostreid herpesvirus-1 (OsHV-1 $\mu$ Var) emerged as the leading cause of mass mortalities (mortalities $>30 \%$ of the population) in Pacific oysters Crassostrea gigas (Barbosa Solomieu et al. 2015, Pernet et al. 2016). OsHV-1 is a DNA virus that is a member of the family Malacoherpesviridae (Lefkowitz et al. 2018). It has since been detected in Ireland (Peeler et al. 2012), Spain (Roque et al. 2012), Italy (Dundon et al. 2011), Scandinavia (Mortensen et al. 2016), New Zealand (Keeling et al. 2014) and Australia (Jenkins et al.

${ }^{*}$ Corresponding author: paul.hick@sydney.edu.au
2013, Barbosa Solomieu et al. 2015, Pernet et al. 2016, Toldrà et al. 2018). In Australia, the seasonal recurrence of Pacific oyster mortality syndrome (POMS) has led to a reduction in Pacific oyster production in New South Wales (NSW) from AU \$2.2 million (2012-2013) to just $\$ 60000$ (2016-2017) (Paul-Pont et al. 2015, NSW-DPI 2018). In 2016, OsHV-1 was detected for the first time in Tasmania, Australia, and has since rapidly spread to the major growing areas, resulting in a loss of up to $78 \%$ of the stock in endemically affected areas during the initial outbreak (de Kantzow et al. 2017, Ugalde et al. 2018). Following this outbreak, over one-third of farmers

(C) The authors 2019. Open Access under Creative Commons by Attribution Licence. Use, distribution and reproduction are unrestricted. Authors and original publication must be credited.

Publisher: Inter-Research · www.int-res.com 
altered their farming practices in order to reduce the impact of OsHV-1 (Ugalde et al. 2018). The substantial impact of OsHV-1 poses a significant risk to the non-endemic, high-value (\$31 million) regions such as South Australia altering oyster production through increased biosecurity measures and reducing the interstate supply of hatchery spat (NSW-DPI 2018).

Detailed investigations have identified considerable temporal and spatial variability in the mortality of oysters caused by OsHV-1 infection, influenced by complex interactions between environmental, host and viral risk factors (Barbosa Solomieu et al. 2015, Whittington et al. 2015a, Pernet et al. 2016). As such, OsHV-1 infection alone is not necessarily associated with mortality (Paul-Pont et al. 2013b). Water temperature is considered to be the most important abiotic factor influencing the seasonal recurrence of POMS; this is supported by farmers' observations and the results of previous studies (Petton et al. 2015, de Kantzow et al. 2016, Ugalde et al. 2018). Mortality events occur when the temperature is between 16 and $24^{\circ} \mathrm{C}$ in Europe (Pernet et al. 2012, Petton et al. 2013, Renault et al. 2014) and 18 to $26^{\circ} \mathrm{C}$ in Australia (Jenkins et al. 2013, Paul-Pont et al. 2014, de Kantzow et al. 2016). Furthermore, mortality varies significantly depending on the growing structure, as illustrated by Pernet et al. (2012), with a survival gain of 50 percentage points in oysters grown on ropes compared to baskets. The significant variability between and within waterways and the numerous interactions between humans and oysters suggests that anthropogenic impacts on OsHV-1 disease expression may be more significant than first thought. Anthropogenic impacts range from the physical stress of farm management practices (de Kantzow et al. 2017) to pressure from increasing waterway degradation and pollution (Moreau et al. 2015a). These stressors potentially reduce oyster ability to defend and acclimate to changing environmental conditions and pathogens.

The commercial oyster production cycle involves frequent handling, grading and translocation of oysters to maximize their growth $\left(\mathrm{O}^{\prime}\right.$ Connor \& Dove 2009, Pogoda et al. 2011). These processes were identified as risk factors for mortality in Tasmania (de Kantzow et al. 2017) and Ireland (Peeler et al. 2012). De Kantzow (2017) demonstrated higher mortality associated with oysters that had been handled for farm management in the week before an OsHV-1 outbreak. These processes involve exposing the oysters to multiple stressors, including both physical trauma (handling and transport) and environmental pressure (altered temperature and air exposure) (Qu et al. 2009), and it is not clear which components con- tribute to the higher susceptibility. Prolonged air exposure has known effects on oysters, including limited feeding opportunities, exposure to varying and potentially extreme temperatures and the depletion oxygen (Guo et al. 2015). Here, prolonged air exposure is defined as emersing the oysters for $24 \mathrm{~h}$, which is significantly longer than the natural range of air exposure experienced in the intertidal environment. Previous investigations have demonstrated that prolonged air exposure of oysters increases catecholamine levels and decreases the $\mathrm{pH}$ of oyster tissue, the integrity of the lysozomal membrane and the expression of antioxidants (Zhang et al. 2006, Allen \& Burnett 2008, Qu et al. 2009, Kuchel et al. 2012). These physiological changes affect key components of the oyster immune system and therefore are likely to affect the response to OsHV-1 infection. An understanding of the specific risk factors that predispose oysters to OsHV-1 disease expression will aid in refining OsHV-1 disease control.

Estuaries are being increasingly contaminated by pesticides with concentrations that vary seasonally, peaking in spring and summer (Brown et al. 2003, Bayen et al. 2007, Renault 2011, Nash 2012). Imidacloprid is a neonicotinoid, an insecticide which acts as an antagonist of the nicotinic acetylcholine receptor in the insect neural system (Liu \& Casida 1993, Buckingham et al. 1997, Matsuda et al. 2001). Since its first patent in 1985, its sales and use have become amongst the fastest growing for insecticides worldwide, with 20000 t produced globally in 2010 (Jeschke et al. 2011, Pollak 2011, Simon-Delso et al. 2015). However, only a small percentage (1.6-20\%) of the pesticide generally reaches its agricultural target, exposing non-target organisms, such as Pacific oysters, to varying concentrations of contamination via spray drift and runoff (Sur 2003, Tisler et al. 2009). Imidacloprid has been increasingly reported in water bodies throughout the world, including in oyster farming areas adjacent to agricultural enterprises and areas of high human activity (Renault 2011). Being sessile filter feeders, oysters are subject to a high risk of interaction with contaminants (Ramu et al. 2007, Bernal-Hernández et al. 2010, Renault 2011). In Sydney water catchments, imidacloprid has been detected in concentrations ranging from 0.04-4.56 $\mu \mathrm{g} \mathrm{l^{-1 }}$ (Sánchez-Bayo \& Hyne 2014). Invertebrates have variable susceptibility to imidacloprid, which causes mortality in mayflies (Ephemeroptera) at $0.3 \mu \mathrm{g} \mathrm{l}^{-1}$ and in Eastern oyster Crassostrea virginica at $145000 \mathrm{\mu g} \mathrm{l}^{-1}$ (Anatra-Cordone \& Durkin 2005). The Pacific oyster C. gigas demonstrated subtle changes in energy and 
antioxidant metabolism when exposed to trace levels $\left(0.1-2 \mathrm{\mu g} \mathrm{l}^{-1}\right)$ of a pesticide mixture of metconazole and isoproturon (Epelboin et al. 2015). Specifically, Pacific oysters exposed to a cocktail of 14 pesticides, including imidacloprid at 1 and $10 \mu \mathrm{g} \mathrm{l}^{-1}$, had increased susceptibility to disease caused by OsHV-1 (Moreau et al. 2015a). There is currently no data on the specific sub-lethal effect of imidacloprid on $C$. gigas, with previous investigations focusing on cocktail effects of pesticides. It is therefore important to investigate the individual effect of imidacloprid due to its significant global usage (especially during 'at-risk periods' of the year) and its known effects on invertebrates. Furthermore, combinations in various pesticide cocktails may increase or decrease the effects of individual pesticides (Renault 2011).

This study aimed to examine the effect of stressors experienced by oysters prior to exposure to OsHV-1 on their susceptibility to OsHV-1. Specifically, we evaluated the role of (1) short-term exposure to the neonicotinoid insecticide imidacloprid at concentrations equivalent to reported environmental contamination and (2) prior exposure to stressors associated with common farm management practices (prolonged air exposure and moderate physical trauma) in disease expression. A controlled laboratory in vivo infection challenge model was used to provide a standardised exposure to OsHV-1 for oysters after various combinations of pesticide and husbandry stressors. An increased understanding of these stressors will aid in guiding farm management practices and regulations for the use of imidacloprid. Even small changes in the mortality of $C$. gigas throughout recurrent OsHV-1 disease outbreaks can translate to critical commercial outcomes for farming enterprises impacted by this disease.

\section{MATERIALS AND METHODS}

\subsection{Oysters}

Apparently healthy Pacific oysters Crassostrea gigas $(\mathrm{n}=725)$ were sourced from a commercial farm in Port Stephens, NSW, in June 2018. These oysters had been grown under commercial growing conditions in floating baskets to 6 mo of age after having been collected from PVC slats on which they had been caught. The mean \pm SD total shell length was $52.35 \pm 7.15 \mathrm{~mm}$. The oysters had no previous exposure to OsHV-1 as this waterway is considered to be free from OsHV-1. This was confirmed by quantita- tive PCR (qPCR) on a random sample at the time of recruitment $(\mathrm{n}=24)$.

POMS is the abnormal mortality of Pacific oysters, defined as mortality $>30 \%$ of the population (Soletchnik et al. 2007). Thus, in the power calculation, the mortality of the reference population (i.e. without stressors applied prior infection with OsHV-1) was set at $30 \%$. For farmers, a $30 \%$ increase in mortality during a POMS event due to anthropogenic stressors may be of sufficient magnitude for them to consider changing farming practices for disease management. Thus, to distinguish an important increase in disease severity above a baseline of $30 \%$ mortality due to OsHV-1, the mortality of the stressed population was set at $60 \%$. We used an online calculator for the power calculation with a specificity of $95 \%$ and a power of 85 and $90 \%$ (Epitools; Ausvet: http://epitools.ausvet.com.au). This indicated a sample size of 55-63 oysters treatment ${ }^{-1}$. Therefore, we decided to use 60 oysters per treatment group challenged with OsHV-1 infection, corresponding to 30 oysters tank ${ }^{-1}$.

\subsection{Experimental system and laboratory housing}

The experiment was conducted in a physical containment level 2 (PC2)-certified aquatic animal facility with a $12 \mathrm{~h}$ light: $12 \mathrm{~h}$ dark cycle at the University of Sydney in Camden, NSW, Australia.

The experimental setup included 4 separate systems, each of which had a 2501 sump attached to a chiller unit (HC-300A; Hailea Aquarium chiller) and a heater to maintain water temperature (Fig. S1 in the Supplement at www.int-res.com/articles/suppl/ q011p685_supp.pdf). Each system distributed water to 6 plastic tanks (Fig. S1). In each tank, a plastic bucket was placed and filled with $9 \mathrm{l}$ of artificial seawater (ASW) at 30\% (measured with a refractometer), prepared with red sea salt (Red Sea) added to de-chlorinated municipal water. Thirty oysters were added to each of these buckets, used as experimental tanks and interdependent of the recirculation system. In the experimental tanks, the water was static.

The use of the systems as a water bath allowed maintenance of the temperature at $22.7 \pm 0.4^{\circ} \mathrm{C}$, optimal for OsHV-1 infection (de Kantzow et al. 2016), in the 24 experimental tanks housing the oysters. The water temperature was monitored daily and recorded using glass thermometers and temperature data loggers (Thermocron DS1921G; Thermodata) placed in numerous tanks to record temperature every $15 \mathrm{~min}$. The room air temperature 
was also maintained at $22^{\circ} \mathrm{C}$ using a reverse cycle air-conditioner (Mitsubishi Electric).

To provide oxygen to the oysters, each experimental tank was equipped with an individual biofilter connected via pipelines to an air-lift pump (KamAir Air Pump model DB40). Water quality was ensured by seeding each biofilter with nitrifying bacteria previously established in marine aquaria housing barramundi Lates calcarifer within the university facilities. To assess water quality, $\mathrm{pH}$ and total ammonia nitrogen (TAN) were measured daily in each experimental tank using the API ${ }^{\circledR}$ saltwater master liquid test kit (Aquarium Pharmaceuticals) according to the manufacturer's instructions. Bicarbonate was added when $\mathrm{pH}$ was $<8.1$, and water was changed when ammonia was $>2 \mathrm{ppm}$, on average once or twice per week.

The oysters were fed once daily with Instant Algae ${ }^{\circledR}$ Shellfish Diet $1800^{\mathrm{TM}}$ (Reed Mariculture) diluted at $1: 10 \mathrm{v} / \mathrm{v}$ with ASW. This diet is a mix of a concentrate of marine microalgae containing Isochrysis sp., Pavlova sp., Thalassiosira weissfloggi, T. pseudonana, Chaetoceros calcitrans and Tetraselmis sp. The quantity of food was calculated according to guidelines for the maintenance rations of oysters provided by the Food and Agriculture Organization (FAO 2004) and Reed Mariculture (Helm 2004).

\subsection{Pre-exposure stress treatments and OsHV-1 challenge}

\subsubsection{Experimental design}

At the start of the experiment on 10 June 2018, oysters were randomly assigned among the 24 experimental tanks $\left(\mathrm{n}=30\right.$ oysters tank $\left.{ }^{-1}\right)$. The oysters were acclimated to the laboratory condition for $7 \mathrm{~d}$ prior to the application of the experimental treatments. At the time of sourcing, the water temperature at the oyster farm was $18^{\circ} \mathrm{C}$. Therefore, during acclimation, the water in the experimental tanks was increased daily by $1^{\circ} \mathrm{C}$ from $18-22^{\circ} \mathrm{C}$.

Following the acclimation period, and before challenge with OsHV-1, the oysters were exposed to different stressors randomly assigned to experimental tanks (Fig. 1). In the first phase, half of the oysters (n $=360$ from $\mathrm{n}=12$ tanks) were exposed to a calculated concentration of $10 \mu \mathrm{g} \mathrm{l}^{-1}$ imidacloprid in tank water for $53 \mathrm{~h}$, while the other oysters were in tanks without this pesticide. In the second phase, some oysters were exposed to physical stressors by being handled 3 times ( $\mathrm{n}=180$ from $\mathrm{n}=6$ tanks) or air-exposed $(\mathrm{n}=$ 180 from $\mathrm{n}=6$ tanks) or both handled and air- exposed ( $\mathrm{n}=180$ from $n=6$ tanks) within $24 \mathrm{~h}$. Other oysters were not exposed to these physical stressors ( $\mathrm{n}=180$ from $\mathrm{n}=6$ tanks). The combination of the presence or absence of imidacloprid exposure and the combinations of physical stressors created 8 treatment groups which were applied to oysters in triplicate tanks (Fig. 1).

Challenge with OsHV-1 was conducted $24 \mathrm{~h}$ after the physical stressors had been completed. In each tank, 15 oysters were relaxed in $\mathrm{MgCl}_{2}$ and challenged by injection. For the 3 replicate tanks of each treatment group, 2 were challenged with OsHV-1 and one was injected with a negative control inoculum (Fig. 1). The remaining 15 oysters in the tanks were used to test for infection by cohabitation.

\subsubsection{Imidacloprid exposure}

A $10 \mathrm{mg} \mathrm{ml}^{-1}$ stock solution was prepared by dissolving imidacloprid (Sigma-Aldrich ${ }^{\circledR}$ ) in $10 \mathrm{ml}$ of methanol. The oysters were exposed to the imidacloprid by addition of this stock solution into the tanks for a final concentration of imidacloprid in each tank of $10 \mu \mathrm{g} \mathrm{l}^{-1}$. Finally, 2 water samples from 2 tanks containing imidacloprid, 2 pools of 4 oysters from imidacloprid-exposed tanks and 1 pool of 4 oysters from a control tank were sent to the National Measurement Institute (https://www.industry.gov. $\mathrm{au} /$ strategies-for-the-future/national-measurementinstitute) for quantification of imidacloprid. The water was changed in all tanks $53 \mathrm{~h}$ after the addition of imidacloprid.

\subsubsection{Physical stress from handling and air exposure}

The handling treatment included depositing the oysters from a tank into a basket used in oyster aquaculture (Seapa ${ }^{\circledR}$ ) and shaking it. The shaking included 10 movements: with the cage held horizontally, shaking it to the right, left, right; then rotating so it was vertical, then rotating $180^{\circ}$ four times; followed by a rapid $360^{\circ}$ rotation; and finally, with the cage held horizontally, shaking down firmly. All movements were standardised and conducted by a single operator. The cage was rinsed with seawater between treatments to prevent crosscontamination with imidacloprid. The handlings were conducted on 19 June 2018 at 11:00 and 14:00 $\mathrm{h}$ and at 10:00 $\mathrm{h}$ the next day. The air-exposure treatment was applied concomitantly with the 


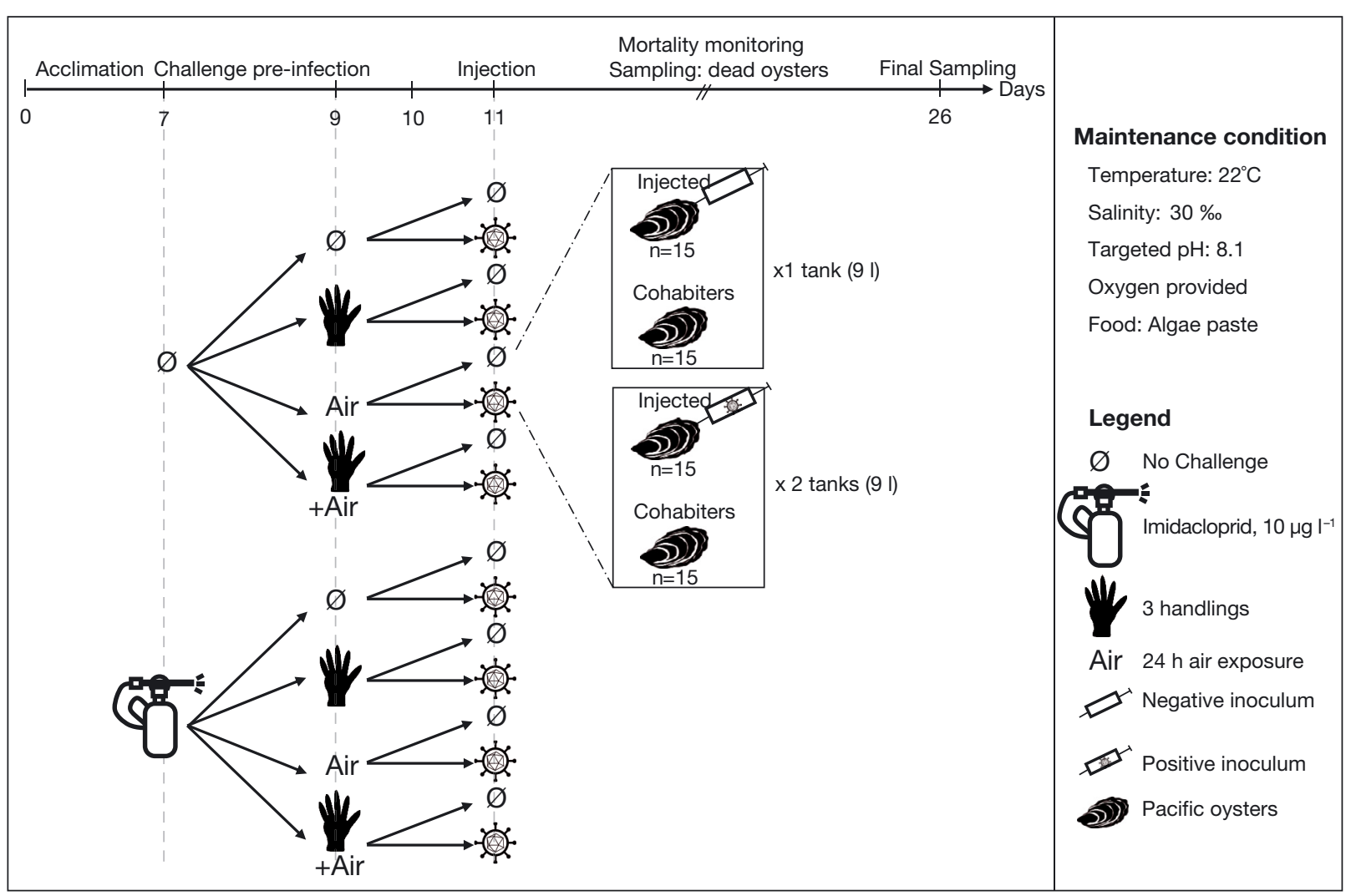

Fig. 1. Experimental design. Pacific oysters were acclimated for $7 \mathrm{~d}$ before being exposed to different combination of factors (imidacloprid [10 $\left.\mathrm{g} \mathrm{l}^{-1}\right]$, handling, air exposure) prior to challenge with OsHV-1 by injection or cohabitation. Following infection, mortality was monitored for $14 \mathrm{~d}$ and dead animals were sampled by qPCR

handling and consisted of placing oysters on the tank lids for $24 \mathrm{~h}$.

\subsection{OsHV-1 infection challenge}

\subsubsection{Preparation of OsHV-1 inoculum}

The OsHV-1 inoculum used in this trial was a cryopreserved stock of OsHV-1 previously used by Evans et al. (2015). This was prepared from OsHV-1-positive mantle and gill tissue from oysters collected from the Georges River, NSW, during an outbreak of OsHV-1 in 2011. The tissues were homogenized and clarified by centrifugation and filtration to $0.2 \mu \mathrm{m}$. This homogenate was cryopreserved with $10 \% \mathrm{v} / \mathrm{v}$ glycerol and $10 \% \mathrm{v} / \mathrm{v}$ foetal bovine serum, and multiple single-use aliquots were stored at $-80^{\circ} \mathrm{C}$. The same process was conducted in 2013 to produce the OsHV-1-negative control inoculum using oysters obtained from disease-free populations in the Shoalhaven River (Goodnight Oysters, Greenwell Point, NSW) that were confirmed negative for OsHV-1 by
qPCR. The cryopreserved inoculums were thawed on ice inside a biosafety cabinet for $10 \mathrm{~min}$ and diluted 1:100 with sterile ASW. Each $50 \mu \mathrm{l}$ of positive inoculum contained $2.39 \times 10^{5}$ viral DNA copies while $50 \mu \mathrm{l}$ of the OsHV-1 negative control inoculum was confirmed negative by qPCR.

\subsubsection{Injection challenge}

Oysters were randomly assigned to the injection challenge. The 15 oysters of each tank to be injected were removed from the water and directly relaxed in a solution of $50 \mathrm{~g} \mathrm{l}^{-1} \mathrm{MgCl}_{2}$ solution at $22^{\circ} \mathrm{C}$ for $4-6 \mathrm{~h}$. These oysters were injected with $50 \mu$ of the inoculum into the adductor muscle using a 25 gauge needle and $1 \mathrm{ml}$ syringe. A small cross was notched onto the left valve using a dremel tool while the oysters were relaxed to distinguish the injected oysters from cohabiter oysters. Oysters assigned to the OsHV-1 negative control challenge were injected first to reduce the risk of cross-contamination. The remaining oysters in each tank were not disturbed during 
this procedure and were challenged by cohabitation in a manner that reflected the outcome of the injection challenge of the cohabiting oysters.

Oyster mortality was assessed twice daily for $14 \mathrm{~d}$ at $12 \mathrm{~h}$ intervals. Oysters were visually inspected, manually handled and classified as dead if they were nonresponsive and failed to close their valves within $3 \mathrm{~min}$ of air exposure. The dead animals were sampled and stored at $-20^{\circ} \mathrm{C}$ before being analysed by qPCR .

\subsubsection{Detection and quantification of OsHV-1 by qPCR}

In total, 240 oysters were tested by a qPCR protocol to quantify OsHV-1 DNA. We used a random selection of stored oysters from each tank as follows: (1) 5 dead injected and 5 dead cohabiter oysters exposed to OsHV-1 inoculum per tank ( $\mathrm{n}=160$ ); and (2) 5 alive injected and 5 alive cohabiter oysters exposed to control inoculum and sampled at the end of the experiment per tank $(\mathrm{n}=80)$.

\subsubsection{Tissue dissection and homogenization}

The oysters stored at $-20^{\circ} \mathrm{C}$ after sampling were thawed at room temperature for $40 \mathrm{~min}$ before being processed. The right valve was removed, and a section of gill and mantle with a combined weight of 0.08-0.12 g was dissected from each oyster using sterile dissecting instruments and deposited into a labelled $1.5 \mathrm{ml}$ tube containing $1 \mathrm{ml}$ of molecular biology-grade distilled water (Ultrapure ${ }^{\mathrm{TM}}$ ) and $0.4 \mathrm{~g}$ of silca-zirconia beads (Daintree Scientific). Samples from each tank and date of mortality were processed separately. Similarly, control and infected oysters (injected and cohabiter) were dissected separately. Work surfaces were disinfected using a $40 \%$ concentration of bleach, and gloves and sterile equipment were used to reduce the risk of cross-contamination. The samples were then stored at $-80^{\circ} \mathrm{C}$ prior to homogenization.

The frozen gill and mantle tissues were thawed for 20 min on ice prior to the mechanical homogenization of the tissues by bead beating. Homogenization was completed with a TissueLyser II machine (Qiagen ${ }^{\circledR}$ ) for $2 \mathrm{~min}$ at a frequency of $30 \mathrm{~Hz}$, and this was repeated after rotating the insert containing the samples $180^{\circ}$. Following this, the samples were centrifuged at $900 \times$ $g$ for 10 min in a microcentrifuge (Heraeus ${ }^{\circledR}$ Biofuge ${ }^{\circledR}$ Pico, Electron Corporation). A volume of $200 \mu$ l of the supernatant was aliquoted into PCR strip tubes in duplicate and stored at $-80^{\circ} \mathrm{C}$ prior to DNA extraction.

\subsubsection{Nucleic acid purification}

Total nucleic acids were purified from $50 \mu \mathrm{l}$ of each clarified tissue homogenate using the MagMAX ${ }^{\mathrm{TM}}$ 96 Viral RNA Isolation Kit (ThermoFisher Scientific $^{\mathrm{TM}}$ ), according to the manufacturer's instructions. A BioSprint 96 Magnetic Particle Processor (Qiagen $\left.{ }^{\circledR}\right)$ was used with the AM1836 deep well standard program (Ambion ${ }^{\circledR}$ Life Technologies ${ }^{\mathrm{TM}}$ ). Nucleic acids were eluted in $75 \mu \mathrm{l}$ of elution buffer and stored at $-20^{\circ} \mathrm{C}$ prior to $\mathrm{qPCR}$ analysis.

\subsection{6. qPCR for detection and quantification OsHV-1 DNA}

A Taqman ${ }^{\circledR}$ assay adapted from Martenot et al. (2010) was used according to a previously described protocol (Evans et al. 2014). Each sample was tested in duplicate. The $25 \mu \mathrm{l}$ reactions were prepared with $12.5 \mu$ of Ambion ${ }^{\circledR}$ Path-ID ${ }^{\mathrm{TM}}$ qPCR Master Mix (ThermoFisher Scientific), $0.225 \mu \mathrm{l}$ each of forward primer (OsHV1BF, 5 -GTC GCA TCT TTG GAT TTA ACA A-3 ), and reverse primers (OSHV1B4, 5 -ACT GGG ATC CGA CTG ACA AC-3 ), $0.625 \mu \mathrm{l}$ OsHV-1 probe (5 -6FAM-TGC CCC TGT CAT CTT GAG GTA TAG ACA ATC-BHQ-3 ), $1 \mu$ of enzyme mix and $5.425 \mu \mathrm{l}$ of nuclease-free water. Each qPCR run included both a positive control of purified nucleic acid from a known OsHV-1-infected oyster and a negative control in addition to a no-template (water) control. The plasmid pOSHV1-Breg (University of Sydney) was used as a quantitative standard by preparing a 10 -fold dilution series containing between $10^{7}$ and $10^{1}$ copies, which were amplified in duplicate. A Mx3000P Real-time PCR machine (Stratgene) was used with the following thermocycling program: hot start activation $95^{\circ} \mathrm{C}$ for $10 \mathrm{~min}, 40$ cycles at $95^{\circ} \mathrm{C}$ for $15 \mathrm{~s}$ and at $60^{\circ} \mathrm{C}$ for $45 \mathrm{~s}$. The fluorescence threshold for each run was calculated using the amplification-based threshold algorithm (Stratagene) based on amplification of the plasmid standard to create a standard curve. The threshold was applied to the experimental samples, and these were considered positive for OsHV-1 DNA when the ROX-normalized and baseline-corrected FAM signal increased exponentially above the threshold. A threshold cycle value was assigned to positive samples as the fractional cycle number when the fluorescence signal first exceeded the threshold. Standard curves were established based on the quantity of OsHV-1 DNA extracted. A valid PCR run was defined by no amplification of the negative control samples, amplification of both replicates of the positive control 
and a standard curve with $\mathrm{r}^{2}>0.95$ and efficiency within the range $90-110 \%$.

\subsection{Statistics}

Water quality, temperature and mortality data for each tank were curated in Excel (Microsoft). Total cumulative mortality (TCM) was calculated as a proportion. TCM was compared across tanks to determine if there was a tank effect on treatment groups. For survival analyses, time of death was determined with a $12 \mathrm{~h}$ resolution. Kaplan Meyer (KM) survival curves were prepared for each treatment group, the tanks and all oysters exposed to imidacloprid, handling and $24 \mathrm{~h}$ air exposure treatments. Survival curves were assessed for significance attributed using a log-rank test $(p<0.05)$. KM survival curves were created in RStudio using the 'survfit' function in the 'survival' package (https://cran.r-project.org/web/packages/ survival/index.html). A Cox proportional hazards model (Cox 1972) accounting for challenge method could not be prepared as this violated the assumptions of the test, even with a correction factor for challenge time during cohabitation. Therefore, a stratified model considering each challenge method separately was prepared with tank as a random effect to assess the hazards of each stressor and any interactions. Confirmation of the assumptions of proportional hazards assumptions were checked according to statistical and graphical tests based on the scaled Schoenfeld residuals. The Cox proportional hazards model was performed in RStudio using the 'coxph' function in the 'survival' package (https://www.rstudio.com/products/ rstudio/download/).

The quantity of OsHV-1 DNA determined by the qPCR was converted to the number of OsHV-1 DNA copies per mg of tissue (mantle and gill) and log transformed to meet the assumption of normality. The quantity of OsHV-1 DNA was compared using a generalized linear mixed model with tank as a random effect, accounting for challenge method (2 levels), imidacloprid (2 levels), handling (2 levels), air exposure ( 2 levels) and all their interactions. Variation in the quantity of DNA copies among treatments was evaluated using the least significant difference test.

The effect of TAN on the survival of oysters following exposure to OsHV-1 was analyzed using a univariate Cox proportional hazards model with dichotomous variables of the cumulative TAN exposure prior to OsHV-1 exposure. Additionally, the average length and width of the oysters that died as a result of POMS was analyzed as a continuous variable in a univariate Cox proportional hazards model. The effect of TAN and the average length and width of the oyster on the quantity of OsHV-1 was determined by ANOVA in RStudio.

\section{RESULTS}

\subsection{Water quality and imidacloprid concentration}

Maintenance of the water quality throughout the experiment resulted in some variations in the levels of salinity, $\mathrm{pH}$ and ammonia (Table S1). The water temperature, salinity and $\mathrm{pH}$ remained within the target range but TAN frequently peaked above the target limit of $2 \mathrm{mg} \mathrm{l}^{-1}$ in all tanks, requiring frequent water changes. However, variation in TAN was examined as a dichotomous variable in which cumulative exposure of $>44 \mathrm{mg} \mathrm{l}^{-1}$ prior to exposure to OsHV-1 had no significant effect on the mortality of the oysters or on the quantity of OsHV-1 ( $p>0.05)$. The imidacloprid concentration (mean $\pm \mathrm{SD}$ ) across the 2 water samples collected $53 \mathrm{~h}$ post pesticide exposure was $12.7 \pm 8.3 \mathrm{~g} \mathrm{l}^{-1}$. The imidacloprid concentration in the oyster tissue was under the limit of detection of $0.5 \mathrm{~g} \mathrm{l}^{-1}$ for the 2 oyster pools from these tanks.

\subsection{Oyster morphology}

Mean \pm SD length and width of the oysters in the experiment was $52.4 \pm 7.2$ and $33.1 \pm 4.9 \mathrm{~mm}$ respectively. Mean whole weight and flesh weight of the oysters was $15.5 \pm 5.3$ and $3.4 \pm 1.6 \mathrm{~g}$ respectively. Length and width had no significant effect on the probability of survival or the concentration of OsHV1 DNA in the oysters at the time of death $(p>0.05)$.

\subsection{Effect of pre-exposure stressors on survival}

There were no mortalities in any of the negative control oysters regardless of pre-exposure stress treatments or challenge method. The earliest time that death occurred in oysters challenged by injection with OsHV-1 and their cohabitaters was $48 \mathrm{~h}$ post-injection. However, the dynamic of mortality was slower for the cohabiters, with substantial mortality not occurring until around $84 \mathrm{~h}$ post-injection (Fig. 2). The median survival time for injected and cohabiter oysters was 72 and $144 \mathrm{~h}$, respectively. TCM differed significantly between challenge methods ( $p$ 
$<0.001$ ) but not between treatment groups (Table 1). The TCM for replicate tanks did not differ significantly, and therefore the data were pooled for analysis.

Survival was reduced in oysters challenged by injection $(24.1 \%)$ in comparison to cohabitation (38.6\%), irrespective of treatment ( $\mathrm{p}<0.001$ ) (Table 1, Fig. 2). The interactive and additive effects between the treatments were not significant $(p>0.05)$ and were removed from the final model. According to the logrank test, there was a significant difference in survival time between donor oysters exposed or not exposed to air $(\mathrm{p}=0.04)$ but not for cohabiters $(\mathrm{p}=$ 0.12). The final survival of oysters exposed to air $24 \mathrm{~h}$ preceding the cohabitation challenge was $44.3 \%$ compared to $33.1 \%$ for the non-air-exposed individuals, and this difference was significant (hazard ratio $=$ 0.77, $p=0.04$; Table 2, Fig. 2). This protective effect of prolonged air exposure was also demonstrated as a trend in the injection challenge (hazard ratio $=0.74$, $\mathrm{p}=0.06$; Table 2, Fig. 2), where the final survival of donors exposed to air was $30 \%$ compared to $17.9 \%$ for the non-exposed individuals.

\subsection{Effect of pre-exposure stressors on the amplification of OsHV-1 DNA}

OsHV-1 was not detected in the negative control oysters. A substantially higher level of OsHV-1 than the inoculum dose was present in challenged oysters at the time of death (Table 1). Therefore, all deaths of the challenged oysters in this trial were attributed to OsHV-1 infection. The viral load at the time of death ranged from $2.15 \times 10^{3}$ to $3.00 \times 10^{7}$ OsHV-1 DNA copies $\mathrm{mg}^{-1}$ tissue in the dead injected oysters, with a median of $6.43 \times 10^{5}$ DNA copies $\mathrm{mg}^{-1}$ tissue. The quantity of OsHV-1 was significantly higher in injected oysters compared to the viral load at the time of death in oysters infected by cohabitation (Table 3 ), which ranged from $1.52 \times 10^{2}$ to $5.11 \times 10^{6}$ OsHV-1 DNA copies $\mathrm{mg}^{-1}$ tissue $(\mathrm{p}<0.001)$, with a median of $2.93 \times 10^{5}$ DNA copies $\mathrm{mg}^{-1}$ tissue (Fig. 3). Application of stress treatments on the oysters before the OsHV-1 challenge did not affect the viral load at the time of mortality ( $p>0.05)$.

\section{DISCUSSION}

Previous investigations have indicated that farm management practices and exposure to pesticides are correlated with exacerbated mortality associated with OsHV-1 (Moreau et al. 2015a, de Kantzow et al.
2017). In this study, results suggest that Pacific oysters Crassostrea gigas can tolerate handling associated with farming practices (such as $24 \mathrm{~h}$ air exposure) and doses of imidacloprid consistent with field observations of waterways (Sánchez-Bayo \& Goka 2006, Yamamoto et al. 2012). In addition, the probability of survival of 6 mo old $C$. gigas increased when exposed to air for $24 \mathrm{~h}$ prior to challenge with OsHV-1. Overall, this result indicates that modulation of disease expression of OsHV-1 by anthropogenic factors is more complex than previously thought. Further investigation is required to determine if the degree of stress, the timing of exposure or combinations of stressors impact the subsequent mortality of Pacific oysters when infected with OsHV-1.

Previous studies have observed that the growing height of baskets and trays of oysters in the intertidal environment is associated with variable levels of disease expression caused by OsHV-1 (Paul-Pont et al. 2013a, Whittington et al. 2015a, Azéma et al. 2017). However, under our experimental conditions, we showed that cohabiter oysters exposed to air for $24 \mathrm{~h}$ prior to challenge with OsHV-1 had significantly higher survival to OsHV-1 compared to those which remained immersed. While non-significant, a similar pattern was observed for the injected oysters. These results suggest that $24 \mathrm{~h}$ emersion at $22^{\circ} \mathrm{C}$ prior to contact with OsHV-1 can have a protective effect against viral infection. The protective effect was likely greater in the oysters challenged by cohabitation since the first barriers of immune defense including the shell, mucosal layer and epithelium were bypassed in the injection challenge (Allam \& Raftos 2015). Hypoxia increases autophagy in multicellular organisms (Moore et al. 2006), and autophagy is a protective mechanism in Pacific oysters against infection by OsHV-1 (Moreau et al. 2015b). In this study, oxygen deprivation during air exposure might have triggered autophagy, explaining the benefit of the $24 \mathrm{~h}$ emersion prior to challenge with OsHV-1, but this needs further investigation. Furthermore, Zhang et al. (2012) demonstrated that air exposure induced a response in a significant number of $C$. gigas genes, several of which are inhibitors of apoptosis (IAPs; the controlled, regulated cell death; part of the development of an organism). IAPs play a critical role in the innate immunity of the oyster, and their up-regulation following emersion is thought to be fundamentally important and responsible for the oysters' tolerance to frequent air exposure (Zhang et al. 2012, Guo et al. 2015). However, these results could differ in different biological settings, as ambient temperatures are often more variable and 

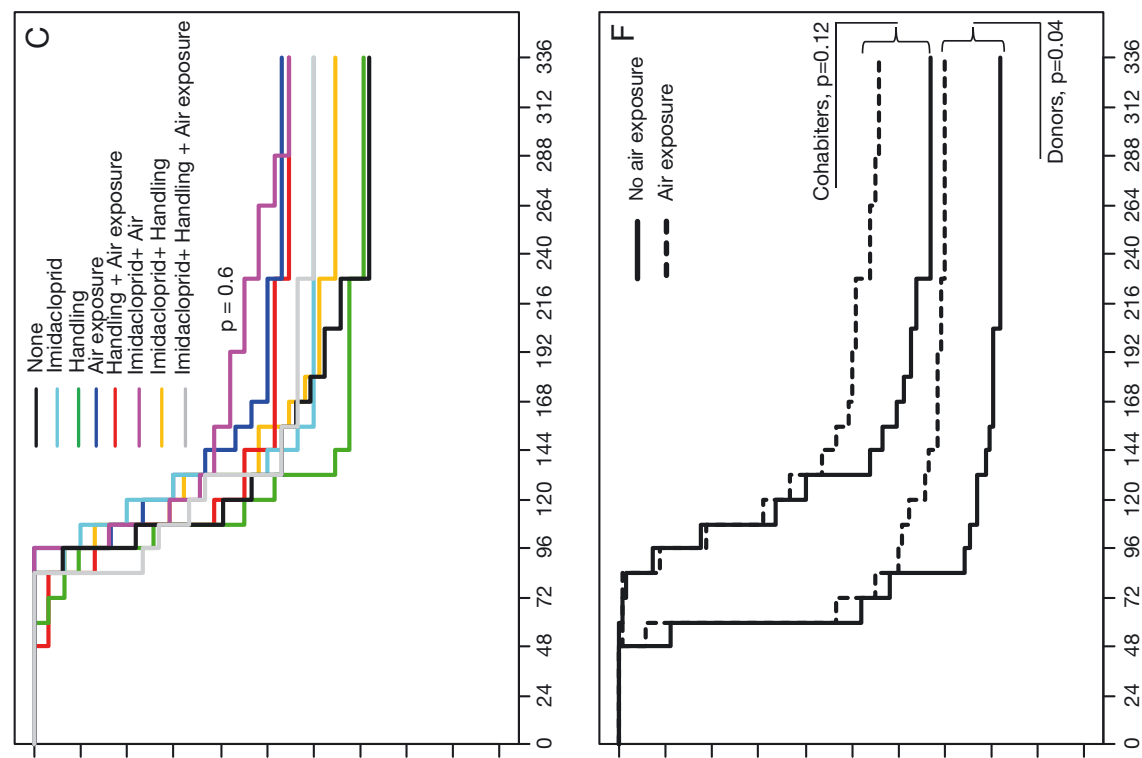

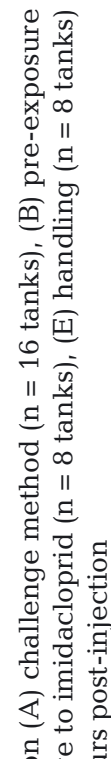
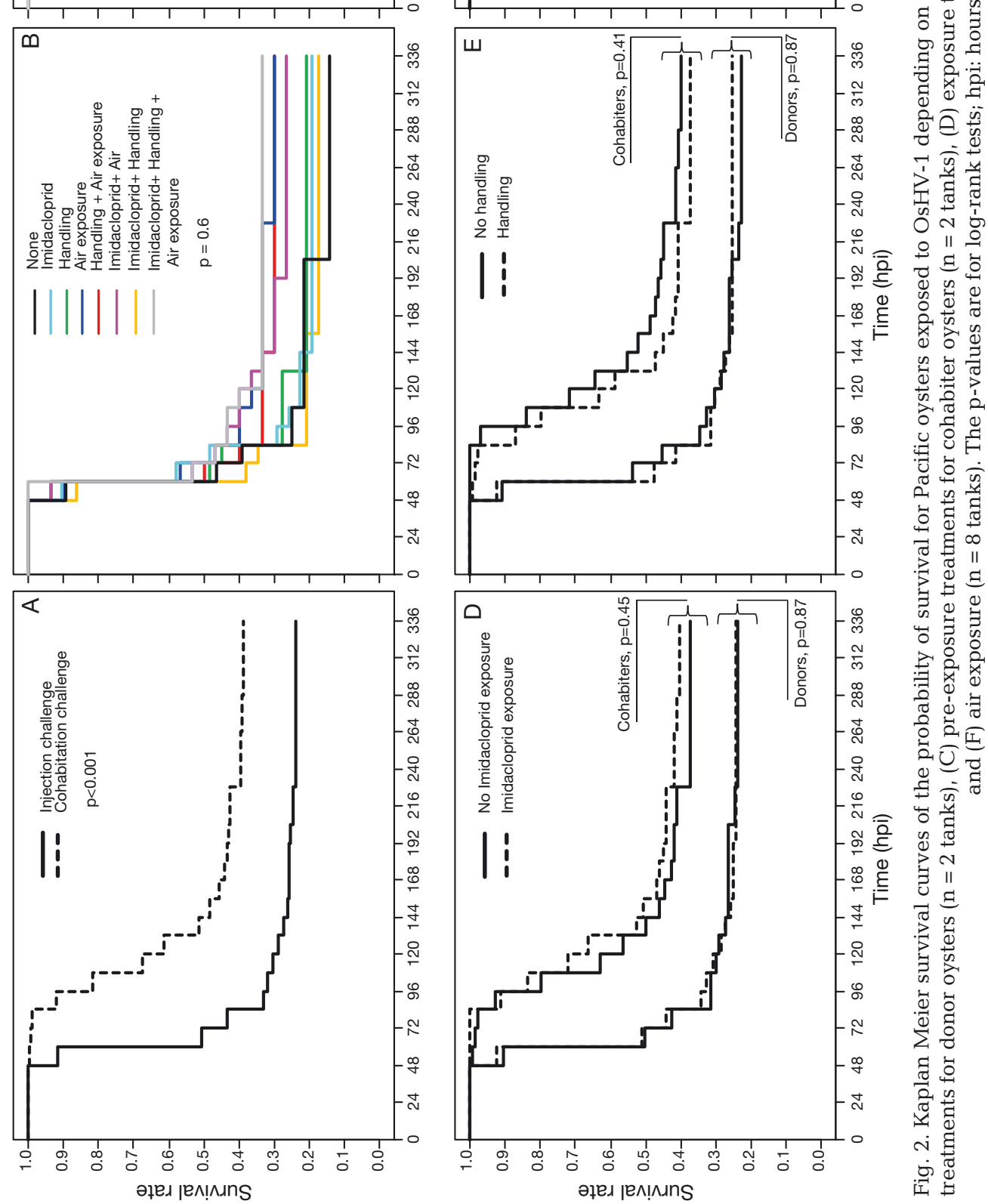
Table 1. Mortality and level of OsHV-1 DNA in Pacific oyster tissues in the different treatments. Data are the mean total cumulative mortality (TCM) for duplicate tanks for each treatment for oysters challenged by injection and cohabitation; quantity of log ${ }_{10}\left(\mathrm{OsHV}_{\mathrm{H}} \mathrm{1}\right.$

DNA copies $\left.\mathrm{mg}^{-1}+1\right)$ in the oysters tested at the time of death $(\mathrm{n}=5$ per tank per challenge method) provided as mean $\pm \mathrm{SE}$

\begin{tabular}{|c|c|c|c|c|c|c|c|c|c|c|}
\hline $\begin{array}{l}\text { Treatment prior } \\
\text { to injection }\end{array}$ & $\begin{array}{l}\text { OsHV-1 } \\
\text { challenge }\end{array}$ & $\begin{array}{c}\text { Tank } \\
\text { number }\end{array}$ & $\begin{array}{c}\text { Oysters } \\
\text { treatment }^{-1}\end{array}$ & $\begin{array}{l}\text { - Inject } \\
\text { TCM } \\
(\%)\end{array}$ & $\begin{array}{l}\text { ed oysters } \\
\text { No. of oys- } \\
\text { ters tested }\end{array}$ & $\begin{array}{c}\text { OsHV-1 } \\
\text { DNA }\end{array}$ & $\begin{array}{c}\text { Oysters } \\
\text { treatment }^{-1}\end{array}$ & $\begin{array}{c}\text { Cohab } \\
\text { TCM } \\
(\%)\end{array}$ & $\begin{array}{l}\text { iter oysters } \\
\text { No. of oys- } \\
\text { ters tested }\end{array}$ & $\begin{array}{c}\text { OsHV-1 } \\
\text { DNA }\end{array}$ \\
\hline None & $\begin{array}{l}\text { No } \\
\text { Yes }\end{array}$ & $\begin{array}{l}1 \\
2\end{array}$ & $\begin{array}{l}15 \\
28\end{array}$ & $\begin{array}{c}0 \\
85\end{array}$ & $\begin{array}{c}5 \\
10\end{array}$ & $\begin{array}{c}0 \\
6.04 \pm 0.17\end{array}$ & $\begin{array}{l}15 \\
32\end{array}$ & $\begin{array}{c}0 \\
72\end{array}$ & $\begin{array}{c}6 \\
10\end{array}$ & $\begin{array}{c}0 \\
5.02 \pm 0.24\end{array}$ \\
\hline Imidacloprid & $\begin{array}{l}\text { No } \\
\text { Yes }\end{array}$ & $\begin{array}{l}1 \\
2\end{array}$ & $\begin{array}{l}15 \\
31\end{array}$ & $\begin{array}{c}0 \\
80\end{array}$ & $\begin{array}{c}5 \\
10\end{array}$ & $\begin{array}{c}0 \\
5.73 \pm 0.19\end{array}$ & $\begin{array}{l}15 \\
30\end{array}$ & $\begin{array}{c}0 \\
60\end{array}$ & $\begin{array}{c}5 \\
10\end{array}$ & $\begin{array}{c}0 \\
5.65 \pm 0.09\end{array}$ \\
\hline Air exposure & $\begin{array}{l}\text { No } \\
\text { Yes }\end{array}$ & $\begin{array}{l}1 \\
2\end{array}$ & $\begin{array}{l}15 \\
30\end{array}$ & $\begin{array}{c}0 \\
70\end{array}$ & $\begin{array}{c}5 \\
10\end{array}$ & $\begin{array}{c}0 \\
5.48 \pm 0.30\end{array}$ & $\begin{array}{l}15 \\
30\end{array}$ & $\begin{array}{c}0 \\
53\end{array}$ & $\begin{array}{c}5 \\
10\end{array}$ & $\begin{array}{c}0 \\
5.44 \pm 0.18\end{array}$ \\
\hline Handling & $\begin{array}{l}\text { No } \\
\text { Yes }\end{array}$ & $\begin{array}{l}1 \\
2\end{array}$ & $\begin{array}{l}15 \\
29\end{array}$ & $\begin{array}{c}0 \\
79\end{array}$ & $\begin{array}{c}5 \\
10\end{array}$ & $\begin{array}{c}0 \\
5.63 \pm 0.14\end{array}$ & $\begin{array}{l}15 \\
31\end{array}$ & $\begin{array}{c}0 \\
70\end{array}$ & $\begin{array}{c}5 \\
10\end{array}$ & $\begin{array}{c}0 \\
4.88 \pm 0.38\end{array}$ \\
\hline $\begin{array}{l}\text { Air exposure + } \\
\text { handling }\end{array}$ & $\begin{array}{l}\text { No } \\
\text { Yes }\end{array}$ & $\begin{array}{l}1 \\
2\end{array}$ & $\begin{array}{l}15 \\
30\end{array}$ & $\begin{array}{c}0 \\
70\end{array}$ & $\begin{array}{c}5 \\
10\end{array}$ & $\begin{array}{c}0 \\
5.66 \pm 0.31\end{array}$ & $\begin{array}{l}15 \\
31\end{array}$ & $\begin{array}{c}0 \\
55\end{array}$ & $\begin{array}{c}5 \\
10\end{array}$ & $\begin{array}{c}0 \\
5.35 \pm 0.34\end{array}$ \\
\hline $\begin{array}{l}\text { Imidacloprid + } \\
\text { air }\end{array}$ & $\begin{array}{l}\text { No } \\
\text { Yes }\end{array}$ & $\begin{array}{l}1 \\
2\end{array}$ & $\begin{array}{l}15 \\
30\end{array}$ & $\begin{array}{c}0 \\
73\end{array}$ & $\begin{array}{c}5 \\
10\end{array}$ & $\begin{array}{c}0 \\
5.71 \pm 0.28\end{array}$ & $\begin{array}{l}15 \\
31\end{array}$ & $\begin{array}{c}0 \\
57\end{array}$ & $\begin{array}{c}5 \\
10\end{array}$ & $\begin{array}{c}0 \\
5.11 \pm 0.30\end{array}$ \\
\hline $\begin{array}{l}\text { Imidacloprid + } \\
\text { handling }\end{array}$ & $\begin{array}{l}\text { No } \\
\text { Yes }\end{array}$ & $\begin{array}{l}1 \\
2\end{array}$ & $\begin{array}{l}15 \\
29\end{array}$ & $\begin{array}{c}0 \\
83\end{array}$ & $\begin{array}{c}5 \\
10\end{array}$ & $\begin{array}{c}0 \\
5.91 \pm 0.14\end{array}$ & $\begin{array}{l}15 \\
31\end{array}$ & $\begin{array}{c}0 \\
65\end{array}$ & $\begin{array}{c}5 \\
10\end{array}$ & $\begin{array}{c}0 \\
4.93 \pm 0.32\end{array}$ \\
\hline $\begin{array}{l}\text { Imidacloprid + } \\
\text { air exposure + } \\
\text { handling }\end{array}$ & $\begin{array}{l}\text { No } \\
\text { Yes }\end{array}$ & $\begin{array}{l}1 \\
2\end{array}$ & $\begin{array}{l}15 \\
30\end{array}$ & $\begin{array}{c}0 \\
67\end{array}$ & $\begin{array}{c}5 \\
11\end{array}$ & $\begin{array}{c}0 \\
5.54 \pm 0.33\end{array}$ & $\begin{array}{l}16 \\
30\end{array}$ & $\begin{array}{c}0 \\
60\end{array}$ & $\begin{array}{c}5 \\
11\end{array}$ & $\begin{array}{c}0 \\
5.41 \pm 0.20\end{array}$ \\
\hline
\end{tabular}

Table 2. Hazard ratios for Pacific oysters predicted from Cox proportional hazards model as a function of challenge method and air exposure. Data are point estimates with $95 \%$ CI. The final model was a stratified model that considered each challenge method separately, with tank as a random effect to assess the hazards of each stressor and any interactions. No air exposure is the reference category

\begin{tabular}{|c|c|c|c|c|c|}
\hline Factor & Level & $\begin{array}{l}\text { Hazard } \\
\text { ratio }\end{array}$ & $\begin{array}{r}95 \% \\
\text { Lower }\end{array}$ & $\begin{array}{l}\text { CI } \\
\text { Upper }\end{array}$ & $\mathrm{p}$ \\
\hline Injected oysters & $\begin{array}{l}24 \mathrm{~h} \text { air exposure } \\
\text { No air exposure }\end{array}$ & $\begin{array}{c}0.74 \\
-\end{array}$ & $\begin{array}{c}0.54 \\
-\end{array}$ & $\begin{array}{c}1.02 \\
-\end{array}$ & $\begin{array}{c}0.06 \\
-\end{array}$ \\
\hline Cohabiter oysters & $\begin{array}{l}24 \mathrm{~h} \text { air exposure } \\
\text { No air exposure }\end{array}$ & $\begin{array}{c}0.77 \\
-\end{array}$ & $\begin{array}{c}0.60 \\
-\end{array}$ & $\begin{array}{c}0.99 \\
-\end{array}$ & $\begin{array}{c}0.04 \\
-\end{array}$ \\
\hline
\end{tabular}

extreme than water due to its innate thermal buffering capacity (Song et al. 2007, Guo et al. 2015, Yang \& Peterson 2017). Previous studies have demonstrated that factors associated with vital immune defenses, including stress responses and the integrity of the lysosomal membrane in bivalve molluscs, are significantly altered when exposed to air temperatures higher than the temperature of the water to which they are acclimated (Zhang et al. 2006, Qu et al. 2009). Therefore, the variable nature of air Table 3. Generalized linear mixed model testing the effect of challenge method, different stressors and their interactions on the level of OsHV-1 DNA in the gill and mantle tissues of dead Pacific oysters

\begin{tabular}{|lccc|}
\hline Treatment & df & $t$ & $\mathrm{p}$ \\
\hline $\begin{array}{l}\text { Challenge method } \\
\text { (injection vs. cohabitation) }\end{array}$ & 145.06 & -3.78 & $<0.001$ \\
Imidacloprid & 7.72 & 0.65 & 0.53 \\
Handling & 7.72 & -0.97 & 0.36 \\
Air exposure & 7.72 & -0.20 & 0.84 \\
Imidacloprid $\times$ handling & 7.90 & -0.03 & 0.97 \\
Imidacloprid $\times$ air exposure & 7.90 & -0.59 & 0.57 \\
Handling $\times$ air exposure & 7.90 & 0.79 & 0.45 \\
Imidacloprid $\times$ handling $\times$ & 7.90 & 0.05 & 0.92 \\
$\quad$ air exposure & & & \\
\hline
\end{tabular}

temperature during periods of prolonged emersion could potentially increase the susceptibility of $C$. gigas to OsHV-1 (Cheng 1983, Lacoste et al. 2001a,b, Li et al. 2005, Aladaileh et al. 2008), as increased water temperatures in summer months are known to be associated with the onset of POMS outbreaks across both Europe and Australia (Paul-Pont et al. 2013b, Petton et al. 2013, Pernet et al. 2014, Ugalde et al. 2018). The quantity of OsHV-1 DNA in oysters at the time of death was not different between oysters exposed to emersion prior to the viral challenge. This suggests that the impact of emersion did not affect the amplification of the virus. Further investigations are required to develop a greater understanding of the protective effect of emersion in con- 


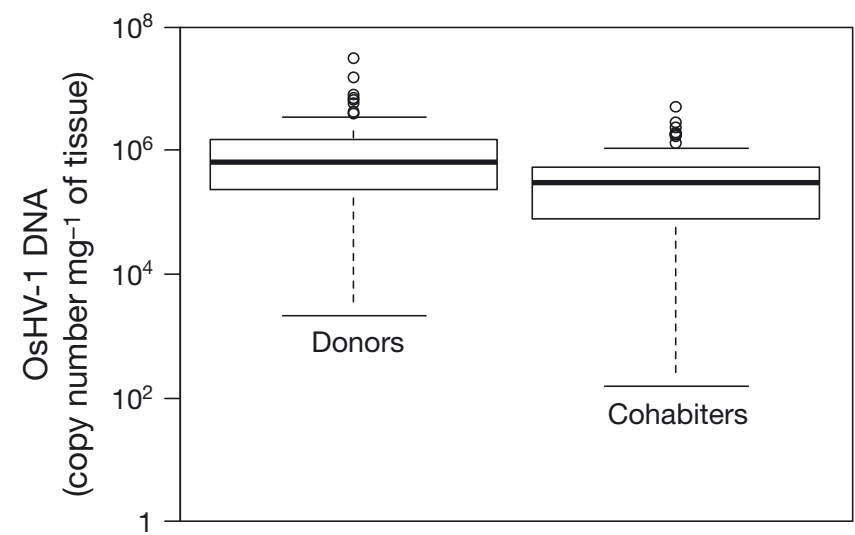

Fig. 3. Level of OsHV-1 DNA at the time of death for Pacific oysters depending on the challenge method used for OsHV-1 exposure; either by injection (donors) or cohabitation (cohabiters). The black bar is the median and the edges of the box indicate the quartiles 1 to 3 . The horizontal bars at the end of the lines are the minimum and maximum values excluding the outliers, indicated as dots. The difference in viral load was significant $(\mathrm{p}<0.001)$

junction with the role of air temperature. This may help clarify how emersion of oysters can be implemented in farm management to improve resilience to OsHV-1.

The frequent handling and grading of oysters is considered by farmers to be a critical risk factor associated with disease expression of OsHV-1 (Qu et al. 2009, Ugalde et al. 2018). Contrary to previous findings, handling did not increase the susceptibility of the oysters to disease associated with OsHV-1 in this study. This suggests that moderate physical handling prior to the onset of disease does not affect the susceptibility of the oysters to POMS. Laboratory-based experiments similarly exploring the individual impact of handling, however, have demonstrated that just $1 \mathrm{~min}$ of centrifugation increased stress factors 5-fold, including circulating noradrenaline (Lafont et al. 2017). This was further emphasized by Lacoste et al. (2002), who demonstrated that a laboratory-controlled 15 min mechanical disturbance of Pacific oysters increased the indicators of stress (haemolymph, noradrenaline and dopamine concentrations) for approximately $8 \mathrm{~h}$. However, the rotation rates (rpm) used in these studies applied a pressure significantly greater than the trauma experienced during farm grading procedures (Lacoste et al. 2002, Lafont et al. 2017). Field studies have identified an association between handling oysters within 1 wk prior to a POMS outbreak and significantly higher mortality (de Kantzow et al. 2017, Renault \& Arzul 2017, Ugalde et al. 2018). However, in de Kantzow et al. (2017), the disturbance included handling the oysters for both routine farm practices and the movement of oysters within and between farms. Therefore, the higher oyster mortality could have been associated with movement among the farms and, more specifically, exposure to new environments rather than handling itself. This is consistent with the hypothesis that the life history of an oyster influences its future susceptibility to disease. This is an important finding, as the handling of oysters is considered by farmers to be a key factor in the expression of POMS, prompting many farmers to adjust handling practices in order to be less intrusive, often at a cost to production (Peeler et al. 2012, Ugalde et al. 2018). Therefore, further research is required to validate the observations of this laboratory study in the field and to understand the underlying metabolic and immune mechanisms involved in oyster response to both handling and prolonged emersion.

Pesticides have been commonly detected in estuaries and coastal areas as a result of anthropogenic activities (Brown et al. 2003, Bayen et al. 2007, Renault 2011, Nash 2012, Starner \& Goh 2012). This study demonstrated that exposing oysters to imidacloprid at $10 \mu \mathrm{g} \mathrm{l}^{-1}$ for $53 \mathrm{~h}$ prior to infection by OsHV-1 did not influence their mortality or the quantity of OsHV-1 in their tissues, suggesting no change in oyster susceptibility. Moreau et al. (2015a) found that exposure of oysters to a combination of 14 pesticides, including imidacloprid for $24 \mathrm{~h}$, increased susceptibility to OsHV-1, although the role of imidacloprid alone at the same concentration as the present study in this cocktail was not determined. There is evidence that combinations of 2 or more pesticides can increase susceptibility of oysters to pathogens through reduced immune functions such as reduced haemocyte phagocytosis (Gagnaire et al. 2007) and changes in the antioxidant system (Epelboin et al. 2015). At a global scale, the effects of imidacloprid on organisms cannot be ignored and require regulation, as sub-lethal effects have been shown to be responsible for reducing immunity, altering behavior and killing non-targeted invertebrates (Alaux et al. 2010, Pettis et al. 2012, Lu et al. 2014).

\section{CONCLUSIONS}

This study demonstrates that $24 \mathrm{~h}$ emersion had a protective effect on oysters that were subsequently exposed to an OsHV-1 challenge. This indicates that extended air exposure potentially triggers underly- 
ing changes in oyster physiology which modulates its disease tolerance. Handling consistent with farm grading did not increase oyster susceptibility to disease caused by OsHV-1. These findings are critical, as farmers may have reduced emersion and handling in the belief that this would reduce the impact of disease caused by OsHV-1 based on previous studies. Further research is now required to validate the observations of this laboratory study in the field and to understand underlying host mechanisms. Although $53 \mathrm{~h}$ exposure to imidacloprid at $10 \mathrm{\mu g} \mathrm{l}^{-1}$ did not influence oyster susceptibility to OsHV-1, as part of a cocktail of pesticides, its effects may be amplified. The global impact of imidacloprid on other components of the ecosystem on a global scale requires further investigation and regulation.

Acknowledgements. This project was supported by funding from the Fisheries Research and Development Corporation (FRDC) and the University of Sydney in conjunction with the research project 'FRDC 2014/040. Oysters Australia IPA: Pacific oyster mortality syndrome, closing knowledge gaps to continue farming Crassostrea gigas in Australia'. We kindly thank Maximillian de Kantzow, Craig Kristo, Stuart Glover, Slavicka Pattern and Alison Tweedie for their technical support. We are thankful to Richard Whittington for valuable discussions on the expressions of disease caused by OsHV-1 in Pacific oysters. We are thankful to Richard Hamlyn-Harris (Endeavor Oysters) for providing the oysters for this study and for the farming advice and field observations from Bruce Alford (Broken Bay Oysters) and Robert Hill. We also thank the National Measurement Institute for carrying out the imidacloprid assays. Finally, we acknowledge 3 anonymous reviewers for providing helpful comments on the manuscript.

\section{LITERATURE CITED}

Aladaileh S, Nair SV, Raftos DA (2008) Effects of noradrenaline on immunological activity in Sydney rock oysters. Dev Comp Immunol 32:627-636

Alaux C, Brunet JL, Dussaubat C, Mondet F and others (2010) Interactions between Nosema microspores and a neonicotinoid weaken honeybees (Apis mellifera). Environ Microbiol 12:774-782

Allam B, Raftos D (2015) Immune responses to infectious diseases in bivalves. J Invertebr Pathol 131:121-136

Allen SM, Burnett LE (2008) The effects of intertidal air exposure on the respiratory physiology and the killing activity of hemocytes in the Pacific oyster, Crassostrea gigas (Thunberg). J Exp Mar Biol Ecol 357:165-171

Anatra-Cordone M, Durkin P (2005) Imidacloprid: human health and ecological risk assessment-final report. USDA Forest Service, Arlington, VA

Azéma P, Lamy JB, Boudry P, Renault T, Travers MA, Dégremont L (2017) Genetic parameters of resistance to Vibrio aestuarianus, and OsHV-1 infections in the Pacific oyster, Crassostrea gigas, at 3 different life stages. Genet Sel Evol 49:23
Azéma P, Maurouard E, Lamy JB, Dégremont L (2017) The use of size and growing height to improve Crassostrea gigas farming and breeding techniques against OsHV-1. Aquaculture 471:121-129

*Barbosa Solomieu V, Renault T, Travers MA (2015) Mass mortality in bivalves and the intricate case of the Pacific oyster, Crassostrea gigas. J Invertebr Pathol 131:2-10

Bayen S, Lee HK, Obbard JP (2007) Exposure and response of aquacultured oysters, Crassostrea gigas, to marine contaminants. Environ Res 103:375-382

*Bernal-Hernández YY, Medina-Diaz IM, Robledo-Marenco ML, Velázquez-Fernández JB and others (2010) Acetylcholinesterase and metallothionein in oysters (Crassostrea corteziensis) from a subtropical Mexican Pacific estuary. Ecotoxicology 19:819-825

*Bown CL, Parchaso F, Thompson JK, Luoma SN (2003) Assessing toxicant effects in a complex estuary: a case study of effects of silver on reproduction in the bivalve, Potamocorbula amurensis, in San Francisco Bay. Hum Ecol Risk Assess 9:95-119

*Buckingham SD, Lapied B, LeCorronc H, Grolleau F, Sattelle DB (1997) Imidacloprid actions on insect neuronal acetylcholine receptors. J Exp Biol 200:2685-2692

Cao C, Wang WX (2016) Bioaccumulation and metabolomics responses in oysters Crassostrea hongkongensis impacted by different levels of metal pollution. Environ Pollut 216:156-165

* Cheng TC (1983) The role of lysosomes in molluscan inflammation. Am Zool 23:129-144

Cox DR (1972) Regression models and life tables. J R Stat Soc Series B Stat Methodol 20:187-220

* de Kantzow M, Hick P, Becker JA, Whittington RJ (2016) Effect of water temperature on mortality of Pacific oysters Crassostrea gigas associated with microvariant ostreid herpesvirus 1 (OsHV-1 $\mu$ Var). Aquacult Environ Interact 8:419-428

de Kantzow MC, Hick PM, Dhand NK, Whittington RJ (2017) Risk factors for mortality during the first occurrence of Pacific oyster mortality syndrome due to Ostreid herpesvirus-1 in Tasmania, 2016. Aquaculture 468:328-336

* Degremont L (2011) Evidence of herpesvirus (OsHV-1) resistance in juvenile Crassostrea gigas selected for high resistance to the summer mortality phenomenon. Aquaculture 317:94-98

*Degremont L (2013) Size and genotype affect resistance to mortality caused by OsHV-1 in Crassostrea gigas. Aquaculture 416-417:129-134

* Degremont L, Nourry M, Maurouard E (2015) Mass selection for survival and resistance to OsHV-1 infection in Crassostrea gigas spat in field conditions: response to selection after 4 generations. Aquaculture 446:111-121

Dundon WG, Arzul I, Omnes E, Robert M and others (2011) Detection of Type 1 Ostreid Herpes variant (OsHV-1 $\mu v a r)$ with no associated mortality in French-origin Pacific cupped oyster Crassostrea gigas farmed in Italy. Aquaculture 314:49-52

*Epelboin Y, Quere C, Pernet F, Pichereau V, Corporeau C (2015) Energy and antioxidant responses of Pacific oyster exposed to trace levels of pesticides. Chem Res Toxicol 28:1831-1841

* Evans O, Paul-Pont I, Hick P, Whittington RJ (2014) A simple centrifugation method for improving the detection of Ostreid herpesvirus-1 (OsHV-1) in natural seawater samples with an assessment of the potential for particulate attachment. J Virol Methods 210:59-66 
FAO (2004) Hatchery culture of bivalves - a practical manual. In: Lovatelli A (ed) FAO Fisheries Technical Paper 471. FAO, Rome, p 203

Fournier M, Cyr D, Blakley B, Boermans H, Brousseau P (2000) Phagocytosis as a biomarker of immunotoxicity in wildlife species exposed to environmental xenobiotics. Am Zool 40:412-420

* Gagnaire B, Gay M, Huvet A, Daniel JY, Saulnier D, Renault $\mathrm{T}$ (2007) Combination of a pesticide exposure and a bacterial challenge: in vivo effects on immune response of Pacific oyster, Crassostrea gigas (Thunberg). Aquat Toxicol 84:92-102

* Guo X, He Y, Zhang L, Lelong C, Jouaux A (2015) Immune and stress responses in oysters with insights on adaptation. Fish Shellfish Immunol 46:107-119

Helm MM (2004) Hatchery culture of bivalves: a practical manual. FAO, Rome

Hick PM, Evans O, Rubio A, Dhand NK, Whittington RJ (2018) Both age and size influence susceptibility of Pacific oysters (Crassostrea gigas) to disease caused by Ostreid herpesvirus-1 (OsHV-1) in replicated field and laboratory experiments. Aquaculture 489:110-120

Jenkins C, Hick P, Gabor M, Spiers Z and others (2013) Identification and characterisation of an Ostreid herpesvirus-1 microvariant (OsHV-1 $\mu$-var) in Crassostrea gigas (Pacific oysters) in Australia. Dis Aquat Org 105: 109-126

Jeschke P, Nauen R, Schindler M, Elbert A (2011) Overview of the status and global strategy for neonicotinoids. J Agric Food Chem 59:2897-2908

Keeling SE, Brosnahan CL, Williams R, Gias E and others (2014) New Zealand juvenile oyster mortality associated with ostreid herpesvirus 1-an opportunistic longitudinal study. Dis Aquat Org 109:231-239

Kuchel RP, Nair S, Raftos DA (2012) Changes in the transcriptional expression of oxidative stress response genes in Akoya pearl oysters (Pinctada fucata) exposed to air and mechanical agitation. Aquaculture 362-363:33-38

Lacoste A, Malham SK, Cueff A, Jalabert F, Gélébart F, Poulet SA (2001a) Evidence for a form of adrenergic response to stress in the mollusc Crassostrea gigas. J Exp Biol 204:1247-1255

Lacoste A, Malham SK, Cueff A, Poulet SA (2001b) Stressinduced catecholamine changes in the hemolymph of the oyster Crassostrea gigas. Gen Comp Endocrinol 122: 181-188

* Lacoste A, Malham SK, Gelebart F, Cueff A, Poulet SA (2002) Stress-induced immune changes in the oyster Crassostrea gigas. Dev Comp Immunol 26:1-9

* Lafont M, Petton B, Vergnes A, Pauletto M, Segarra A, Gourbal B, Montagnani C (2017) Long-lasting antiviral innate immune priming in the lophotrochozoan Pacific oyster, Crassostrea gigas. Sci Rep 7:13143

Lefkowitz EJ, Dempsey DM, Hendrickson RC, Orton RJ, Siddell SG, Smith DB (2018) Virus taxonomy: the database of the International Committee on Taxonomy of Viruses (ICTV). Nucleic Acids Res 46:D708-D717

Lejart M, Hily C (2011) Differential response of benthic macrofauna to the formation of novel oyster reefs (Crassostrea gigas, Thunberg) on soft and rocky substrate in the intertidal of the Bay of Brest, France. J Sea Res 65: 84-93

Li JT, Lee PP, Chen OC, Cheng W, Kuo CM (2005) Dopamine depresses the immune ability and increases susceptibility to Lactococcus garvieae in the freshwater giant prawn, Macrobrachium rosenbergii. Fish Shellfish Immunol 19:269-280

ㄴ Liu MY, Casida JE (1993) High affinity binding of $\left[{ }^{3} \mathrm{H}\right]$ imidacloprid in the insect acetylcholine receptor. Pestic Biochem Physiol 46:40-46

Lu CS, Warchol KM, Callahan RA (2014) Sub-lethal exposure to neonicotinoids impaired honey bees winterization before proceeding to colony collapse disorder. Bull Insectol 67:125-130

Lynch SA, Carlsson J, Culloty SC (2011) Investigation into the involvement of ostreid herpes virus 1 (OsHV-1) in summer mortalities of Pacific oyster, Crassostrea gigas, spat and market sized adults in Ireland. J Shellfish Res 30:528-529

* Lynch SA, Carlsson J, Reilly AO, Cotter E, Culloty SC (2012) A previously undescribed ostreid herpes virus 1 (OsHV1) genotype detected in the Pacific oyster, Crassostrea gigas, in Ireland. Parasitology 139:1526-1532

Main AR, Headley JV, Peru KM, Michel NL, Cessna AJ (2014) Widespread use and frequent detection of neonicotinoid insecticides in wetlands of Canada's Prairie Pothole Region. PLOS ONE 9:e92821

*Matsuda K, Buckingham SD, Kleier D, Rauh JJ, Grauso M, Sattelle DB (2001) Neonicotinoids: insecticides acting on insect nicotinic acetylcholine receptors. Trends Pharmacol Sci 22:573-580

* Moore MN, Allen JI, Somerfield PJ (2006) Autophagy: role in surviving environmental stress. Mar Environ Res 62: S420-S425

Moreau P, Burgeot T, Renault T (2014) Pacific oyster (Crassostrea gigas) hemocyte are not affected by a mixture of pesticides in short-term in vitro assays. Environ Sci Pollut Res 21:4940-4949

* Moreau P, Faury N, Burgeot T, Renault T (2015a) Pesticides and Ostreid herpesvirus 1 infection in the Pacific oyster, Crassostrea gigas. PLOS ONE 10:e0130628

*Moreau P, Moreau K, Segarra A, Tourbiez D, Travers MA, Rubinsztein DC, Renault T (2015b) Autophagy plays an important role in protecting Pacific oysters from OsHV-1 and Vibrio aestuarianus infections. Autophagy 11: 516-526

Mortensen S, Strand A, Bodvin T, Alfjorden A and others (2016) Summer mortalities and detection of ostreid herpesvirus microvariant in Pacific oyster Crassostrea gigas in Sweden and Norway. Dis Aquat Org 117: 171-176

Nash C, Rubio A (2012) Monitoring the canaries of our catchments. Presented at the $21^{\text {st }}$ NSW Coastal Conference, 6-9 November 2012, Kiama

*Nikapitiya C, McDowell IC, Villamil L, Muñoz P, Sohn S, Gomez-Chiarri M (2014) Identification of potential general markers of disease resistance in American oysters, Crassostrea virginica through gene expression studies. Fish Shellfish Immunol 41:27-36

NSW-DPI (New South Wales Department of Primary Industries) (2018) Aquaculture production report 2016-2017. Department of Primary Industries, Port Stephens

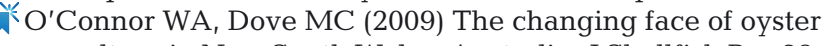
culture in New South Wales, Australia. J Shellfish Res 28: 803-811

\% Oden E, Martenot C, Berthaux M, Travaille E, Malas JP, Houssin M (2011) Quantification of ostreid herpesvirus 1 (OsHV-1) in Crassostrea gigas by real-time PCR: determination of a viral load threshold to prevent summer mortalities. Aquaculture 317:27-31 
Paul-Pont I, Dhand NK, Whittington RJ (2013a) Influence of husbandry practices on OsHV-1 associated mortality of Pacific oysters Crassostrea gigas. Aquaculture 412-413: 202-214

Paul-Pont I, Dhand NK, Whittington RJ (2013b) Spatial distribution of mortality in Pacific oysters Crassostrea gigas: reflection on mechanisms of OsHV-1 transmission. Dis Aquat Org 105:127-138

*Paul-Pont I, Evans O, Dhand NK, Rubio A, Coad P, Whittington RJ (2014) Descriptive epidemiology of mass mortality due to Ostreid herpesvirus-1 (OsHV-1) in commercially farmed Pacific oysters (Crassostrea gigas) in the Hawkesbury River estuary, Australia. Aquaculture 422423:146-159

Paul-Pont I, Evans O, Dhand NK, Whittington RJ (2015) Experimental infections of Pacific oyster Crassostrea gigas using the Australian Ostreid herpesvirus-1 (OsHV1) $\mu$ Var strain. Dis Aquat Org 113:137-147

*Peeler EJ, Reese RA, Cheslett DL, Geoghegan F, Power A, Thrush MA (2012) Investigation of mortality in Pacific oysters associated with Ostreid herpesvirus-1 $\mu$ Var in the Republic of Ireland in 2009. Prev Vet Med 105:136-143

Pernet F, Barret J, Le Gall P, Corporeau C and others (2012) Mass mortalities of Pacific oysters Crassostrea gigas reflect infectious diseases and vary with farming practices in the Mediterranean Thau lagoon, France. Aquacult Environ Interact 2:215-237

Pernet F, Lagarde F, Jeannee N, Daigle G and others (2014) Spatial and temporal dynamics of mass mortalities in oysters is influenced by energetic reserves and food quality. PLOS ONE 9:e88469

* Pernet F, Lupo C, Bacher C, Whittington RJ (2016) Infectious diseases in oyster aquaculture require a new integrated approach. Phil Trans R Soc B 371:20150213

Pettis JS, vanEngelsdorp D, Johnson J, Dively G (2012) Pesticide exposure in honey bees results in increased levels of the gut pathogen Nosema. Naturwissenschaften 99: 153-158

* Petton B, Pernet F, Robert R, Boudry P (2013) Temperature influence on pathogen transmission and subsequent mortalities in juvenile Pacific oysters Crassostrea gigas. Aquacult Environ Interact 3:257-273

Petton B, Boudry P, Alunno-Bruscia M, Pernet F (2015) Factors influencing disease-induced mortality of Pacific oysters Crassostrea gigas. Aquacult Environ Interact 6: 205-222

* Pogoda B, Buck BH, Hagen W (2011) Growth performance and condition of oysters (Crassostrea gigas and Ostrea edulis) farmed in an offshore environment (North Sea, Germany). Aquaculture 319:484-492

Pollak P (2011) Fine chemicals: the industry and the business. John Wiley \& Sons, Hoboken, NJ

$\mathrm{Qu} \mathrm{Y}, \mathrm{Li} \mathrm{XX}, \mathrm{Yu}$ Y, Vandepeer M and others (2009) The effect of different grading equipment on stress levels assessed by catecholamine measurements in Pacific oysters, Crassostrea gigas (Thunberg). Aquacult Eng 40: $11-16$

Ramu K, Kajiwara N, Isobe $\mathrm{T}$, Takahashi $\mathrm{S}$ and others (2007) Spatial distribution and accumulation of brominated flame retardants, polychlorinated biphenyls and organochlorine pesticides in blue mussels (Mytilus edulis) from coastal waters of Korea. Environ Pollut 148: 562-569

Renault T (2011) Effects of pesticides on marine bivalves: What do we know and what do we need to know? In:
Stoytcheva M (ed) Pesticides in the modern world-risks and benefits. InTech, Rijeka, p 227-240

Renault T, Arzul I (2017) Infection with ostreid herpesvirus 1 microvariants. In: Manual of diagnostic tests for aquatic animals. World Organisation for Animal Health (OIE), Paris

Kenault T, Bouquet al. Maurice JT, Lupo C, Blachier P (2014) Ostreid herpesvirus 1 infection among Pacific oyster (Crassostrea gigas) spat: relevance of water temperature to virus replication and circulation prior to the onset of mortality. Appl Environ Microbiol 80:5419-5426

Koque A, Carrasco N, Andree KB, Lacuesta B and others (2012) First report of OsHV-1 microvar in Pacific oyster (Crassostrea gigas) cultured in Spain. Aquaculture 324235:303-306

* Sánchez-Bayo F, Goka K (2006) Influence of light in acute toxicity bioassays of imidacloprid and zinc pyrithione to zooplankton crustaceans. Aquat Toxicol 78:262-271

Sánchez-Bayo F, Hyne RV (2014) Detection and analysis of neonicotinoids in river waters - development of a passive sampler for 3 commonly used insecticides. Chemosphere 99:143-151

Simon-Delso N, Amaral-Rogers V, Belzunces LP, Bonmatin JM and others (2015) Systemic insecticides (neonicotinoids and fipronil): trends, uses, mode of action and metabolites. Environ Sci Pollut Res 22:5-34

* Soletchnik P, Ropert M, Mazurié J, Fleury PG, Le Coz F (2007) Relationships between oyster mortality patterns and environmental data from monitoring databases along the coasts of France. Aquaculture 271:384-400

* Song L, Li X, Clarke S, Wang T, Bott K (2007) The effect of size on the response of Pacific oysters (Crassostrea gigas) to changes in water temperature and air exposure. Aquacult Int 15:351-362

* Starner K, Goh KS (2012) Detections of the neonicotinoid insecticide imidacloprid in surface waters of three agricultural regions of California, USA, 2010-2011. Bull Environ Contam Toxicol 88:316-321

Sur R, Stork A (2003) Uptake, translocation and metabolism of imidacloprid in plants. Bull Insectol 56:35-40

* Tisler T, Jemec A, Mozetic B, Trebse P (2009) Hazard identification of imidacloprid to aquatic environment. Chemosphere 76:907-914

Toldrà A, Andree KB, Bertomeu E, Roque A and others (2018) Rapid capture and detection of Ostreid herpesvirus-1 from Pacific oyster Crassostrea gigas and seawater using magnetic beads. PLOS ONE 13:e0205207

* Ugalde SC, Preston J, Ogier E, Crawford C (2018) Analysis of farm management strategies following herpesvirus (OsHV-1) disease outbreaks in Pacific oysters in Tasmania, Australia. Aquaculture 495:179-186

Wei L, Wang Q, Wu H, Ji C, Zhao J (2015) Proteomic and metabolomic responses of Pacific oyster Crassostrea gigas to elevated $\mathrm{pCO}_{2}$ exposure. J Proteomics 112:83-94

*Whittington RJ, Dhand NK, Evans O, Paul-Pont I (2015a) Further observations on the influence of husbandry practices on OsHV-1 $\mu$ Var mortality in Pacific oysters Crassostrea gigas: age, cultivation structures and growing height. Aquaculture 438:82-97

Whittington RJ, Hick P, Evans O, Rubio A, Alford B, Dhand N, Paul-Pont I (2015b) Protection of Pacific oyster (Crassostrea gigas) spat from mortality due to ostreid herpesvirus 1 (OsHV-1 $\mu$ Var) using simple treatments of incoming seawater in land-based upwellers. Aquaculture 437:10-20 
Yamamoto A, Terao T, Hisatomi H, Kawasaki H, Arakawa R (2012) Evaluation of river pollution of neonicotinoids in Osaka City (Japan) by LC/MS with dopant-assisted photoionisation. J Environ Monit 14:2189-2194

Yang D, Peterson A (2017) River water temperature in relation to local air temperature in the Mackenzie and Yukon basins. Arctic 70:47-58

Editorial responsibility: Sophie St-Hilaire, Kowloon, Hong Kong SAR
Zhang ZH, Li XX, Vandepeer M, Zhao W (2006) Effects of water temperature and air exposure on the lysosomal membrane stability of hemocytes in Pacific oysters, Crassostrea gigas (Thunberg). Aquaculture 256:502-509

* Zhang G, Fang X, Guo X, Li L and others (2012) The oyster genome reveals stress adaptation and complexity of shell formation. Nature 490:49-54

Submitted: February 4, 2019; Accepted: September 23, 2019 Proofs received from author(s): December 2, 2019 